\title{
Transformation of the silhouette of the urban space. Jelgava example
}

\author{
Aija Ziemeḷniece, Latvia University of Agriculture
}

\begin{abstract}
Through hundreds of years, the silhouette of Jelgava with church spires has changed several times. The culmination of the expression existed until World War II when the city was cruelly devastated and the restoration of the historic building was ignored. With the change of the political power, the city skyline changes alongside with it where the public understanding of the cultural values is readable. This statement is brightly confirmed by the comparison of the public attitude of the prewar and postwar time where the prewar political power is with a higher understanding of religious values and the role of churches in the society and the urban environment. In turn, the postwar policy stance during the $\mathbf{2 0}^{\text {th }}$ century brings in Latvia hatred towards cultural values. The urban construction space is a vivid example of the above mentioned. Thanks to the archive material it is possible to determine the progress of transformation processes of the historical urban environment.
\end{abstract}

Key words: silhouette, church spires, compositional solution, urban space, cultural and historical heritage

\section{Introduction}

In the race of the centuries, the skyline of the city of Jelgava is repeatedly admired in engravings (Fig. 1, 2, 3). It is possible to compare the historical building of the city and the modern building situation by studying archival materials.

The church towers of Jelgava are witnesses of the ethnically and confessionally varied composition of the townspeople, which formed in the times of the Duchy of Courland and the Tsarist Russian protectorate [8;2]. The palette of the ethnic composition featured in the architecture of the churches of each confession which, in turn, enriched the expression of the city's silhouette. The multicolor confessions Catholic, Lutheran, Reformer, Orthodox, and Jewish showed high economic development. According to the statistical data, in 1935, by their faith, people of Jelgava were distributed as follows: Ev. Lutherans - $77.1 \%$, Catholics $9.5 \%$, Orthodox $-4 \%$, Old Believers - $1.9 \%$, Moses believers - $6 \%$, the rest $-1.5 \%$ [1]. Not only the church spires were readable in the silhouette but also buildings of functionally different meaning - Town Hall, Fire Tower, residential buildings, Water Tower, the dome-shaped roof of the gas station. After the research of the archival materials and their systematization, the aim of the research is connected with the assessment of the silhouette of the historical and the modern Jelgava.

Several research assignments are defined for the assessment of the transformation processes of the urban construction space which are as follows:

- the assessment of the criteria of the structure of development of the historical urban space;
- the position of the historical churches in building of the river bank, their urban construction context in the assessment of the silhouette;

- the study of the visual shape of the silhouette in the contemporary situation.

The main method of research is based on the study of the historical archival materials and the comparison of the obtained results with the modern urban construction structure for the left bank of the river Driksa.

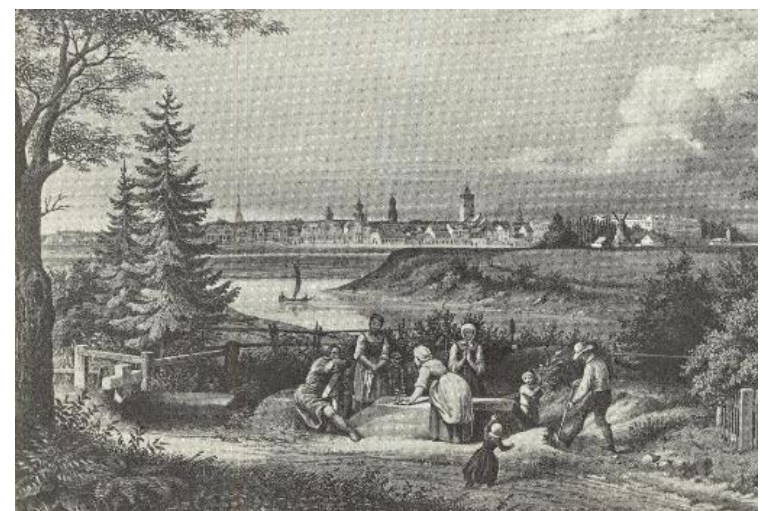

Fig. 1. The city skyline from Kalnakrogs Cemetery T. Miller's engraving (1852) [9]

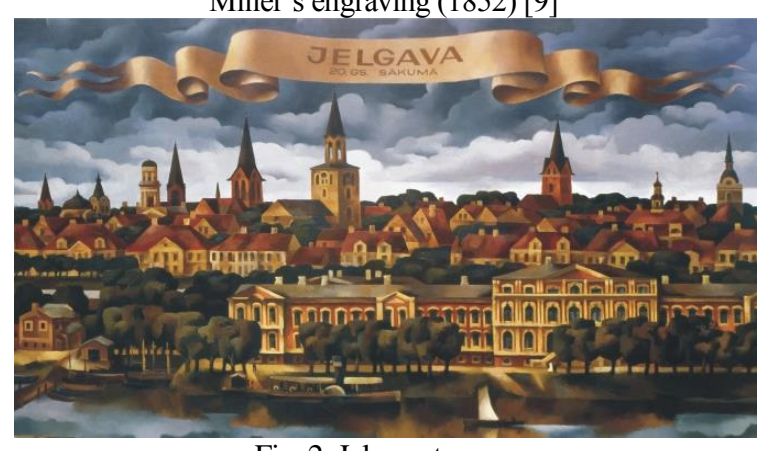

Fig. 2. Jelgava towers

[Source: M. Stumbris, oil, 2000] 


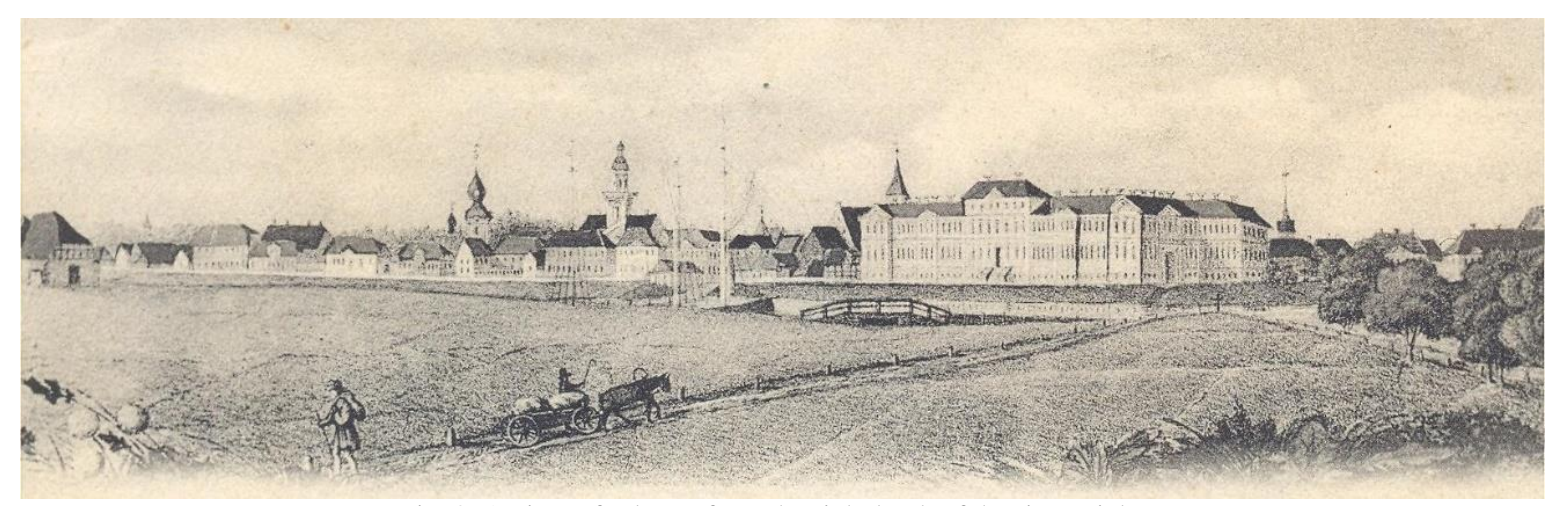

Fig. 3. A view of Jelgava from the right bank of the river Lielupe

[Source: the middle of the 18th century, JHAM]

\section{Materials and methods}

Both the historical map material of Jelgava and the ancient engravings show a peculiar silhouette of the city with many of church spires. With the development of the opportunities of the photographic image, the documentary material, especially brightly between the 20 s and 30 s of the $20^{\text {th }}$ century suggest of the expressiveness of the historic city skyline. Thanks to the documented material, it is possible to carry out the study of the urban construction space by individual zones of the church building.

The historical building of Jelgava has an expressed linearly stretched building along the left bank of the river Driksa where opposite the place of the seat of the Duchy, the grandest houses of the German aristocracy were located. In the historic urban environment, the embankment of the river Driksa was formed as the most elite place of the building location. Up to the $40 \mathrm{~s}$ of the $20^{\text {th }}$ century, in the study materials of the city skyline, several church spires are visible that are brought closer, as well as away from the river bank (Fig. 13).

The silhouette of Jelgava as the Duchy and later the capital of the times of the governorate has changed several times. The attractiveness of the city silhouette has already been admired in the $17^{\text {th }}$ century, in the engravings reflecting the ancient fortified castle of the Livonian times [5]. Through the construction of the new castle of the Duchy in the early $18^{\text {th }}$ century, several church spires and the character of the urban settlement are readable in the silhouette along the bank of the river Driksa. The same is true of the $19^{\text {th }}$ century T. Miller's engraving (Fig. 1). After the war, with the destruction of the city, the panorama of the bank of the river Driksa has drastically changed.

For the perception of the city skyline, the lines of sight are located on the driveway from Riga and from the viewpoints of Pilssala and Pasta sala. The length of the silhouette of the city's historical building along the river Driksa exceeded $1 \mathrm{~km}$ in the start of the $40 \mathrm{~s}$ of the $20^{\text {th }}$ century. The reference points of the length of the panorama line are the southern and northern edges of the old city ramparts and its canal, upstream and downstream the river Driksa. The city's ramparts exist until 1804, then they is dismantled. The distance between the ends of the ramparts is approximately $1 \mathrm{~km}$. Downstream the river Driksa or at the north end of the city the former Reformed or Calvinist church was located (1899) [8]. The church was built in a solid building line on Uzvaras street which formed a vertical dominant for the closing of Dobele street near Uzvaras street (Fig. 4). As a vertical accent, it concluded the city skyline in the northern part. The church had typical features of the Baroque style - thickly profiled ledges, ellipses, and windows of a semi-circular form, a Neo-Baroque tower spire [8].

Today, the historical location of the Reformed Church is marked by the old trees, circumferentially planted around the altar part of the church (Fig. 8). Close to the church's location, in the postwar years, a 4-storied school corps was built, bringing in the urban silhouette another scale and compositional point of gravity.

In the building on Uzvaras street, the position of the Reformed Church marked the road or the socalled place of the Northern Gate, leading out of town in the direction of the sea. In turn, in the southern direction, Uzvaras street was connected to the Market Square. It was decorated by 3 tower spires, so emphasizing the part of the city center.

As the first which was readable in the silhouette of the Reformed Church in the distance of $150 \mathrm{~m}$ was the Fire Tower (Fig. 5). The height of the tower was sufficient to view the city's rooftops. $80 \mathrm{~m}$ away from it, the Town Hall (1743) was located which was decorated by a spire (approximately $22 \mathrm{~m}$ ). Both the spire of the Fire Tower and the Town Hall tower were relatively lower than the Reformed Church. The highest spire of the Town Hall and the city was the German Ev. Lutheran Holy Trinity Church. It was located opposite the castle on the opposite bank of the river and with its impressive building volume symbolized the importance of the 


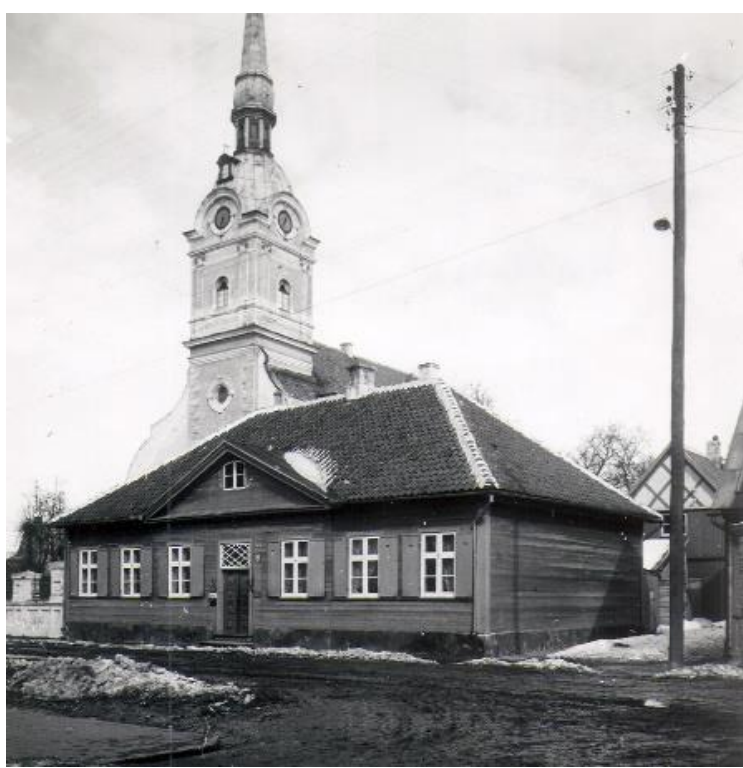

Fig. 4. The former Reformed Church on Uzvaras street [Source: JHAM]

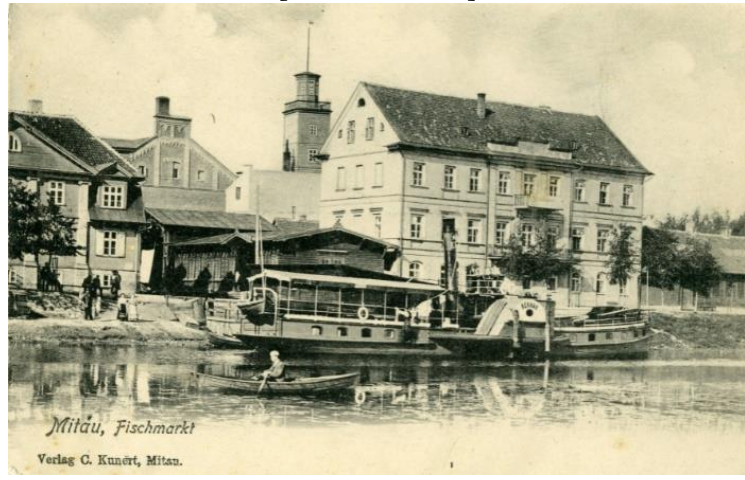

Fig. 5. The former Fire Tower was at the Market Square The early $20^{\text {th }}$ century [Source: JHAM]

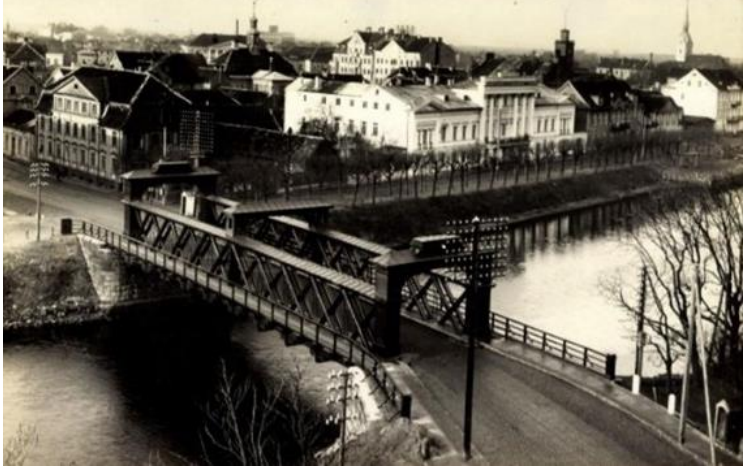

Fig. 6. A view to the Courland Chivalry House, Town Hall, Fire Tower and Reformed Church. The early 20th century [Source: JHAM]

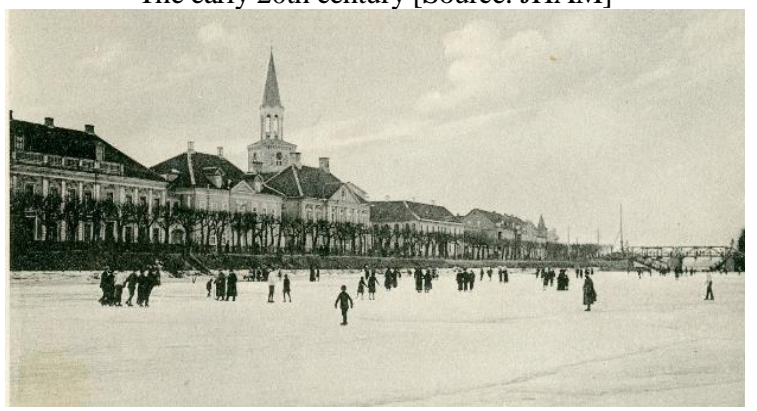

Fig. 7. A silhouette of the city with the tower Holy Trinity Church. The early $20^{\text {th }}$ century [Source: JHAM] capital city of the Duchy of Courland and the times of the governorate. The church was circumferentially surrounded by a 2 -storey building. The scale of the church spire compositionally strongly contained the structure of the urban construction space. This is attributable to the lines of sight which opened from Pilssala, Pasta sala, the Market Square or Akadēmijas street. The bell tower remaining after the war has obtained a provisional nature of roofing without a spire. Nowadays, the silhouette around the Holy Trinity Church is supplemented by a new bridge and a seamless 4-5 floor building line along the bank of the river Driksa (Fig. 9). In the lines of sight from the bridge over the river Driksa, upon entering the city, in the skyline until the 30 s of the $20^{\text {th }}$ century clearly dominated the massive facade of the Kurzeme Chivalry House that in individual viewpoints from the bridge of the river Driksa hid the spire of the Town Hall or the Fire Tower. During the times of the first free state, the Chivalry House representing the German power was dismantled and a 3-storey hotel was built in this place in the $30 \mathrm{~s}$ of the $20^{\text {th }}$ century. During the war, the city was burned down and after the war, in the place of the Town Hall and the Fire Tower, a high-rise residential building was built. The new building scale, density, and structure brought a different compositional character of the urban space in the silhouette. With disappearing of the tower spires around the former Market Square, the visual perception of the city's old place of the center has gone.

These four spires emphasized the historical part of the city center with a solid two-storey or threestorey building, which was decorated by pitched redtiled roofs around the Market Square. Both in the colorfulness and composition, the tower spires and the roof landscape left a lasting impression on the city's grandeur to the driver. The historic place of the bridge over the river Driksa has survived into the present, so it is easy to imagine the character of the old building. Nowadays, the street is widened and it has lines of tree plantations. When comparing the former Market Square with the installed green square instead, it can be seen that the form of the adjacent high- rise building, street, and square creates a new situation of the urban construction.

The southern part of the historical silhouette upstream the river Driksa was formed by a zone of church towers which started in the distance of $200 \mathrm{~m}$ from the Holy Trinity Church. Together, in the distance of 100-200 m, there was a synagogue, Academia Petrina, St. George's Church, St. Simeon's and St. Anne's Church, Nikolai Church (Fig. 10).

The last three ones are in the distance of $100-300 \mathrm{~m}$ from the bank of the river but their 


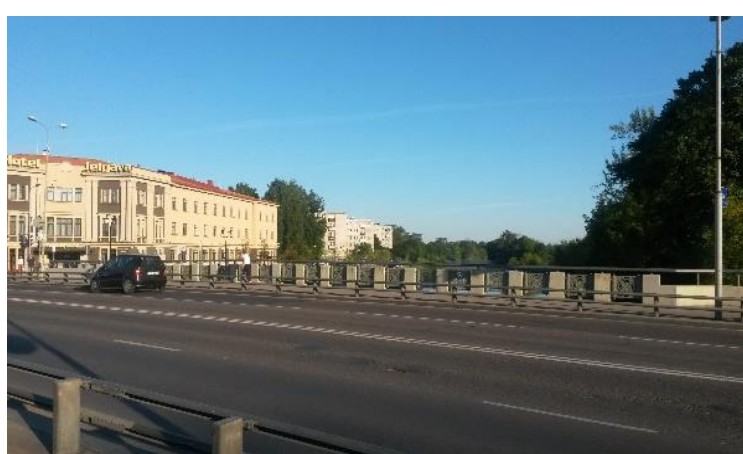

Fig. 8. Today, view to the Hotel [Source: photo by author, 2017]

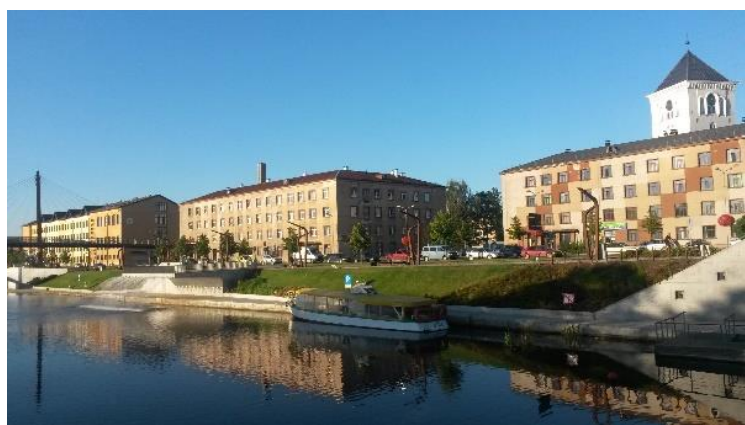

Fig. 9. Silhouette around the Holy Trinity Church [Source: photo by author, 2017]

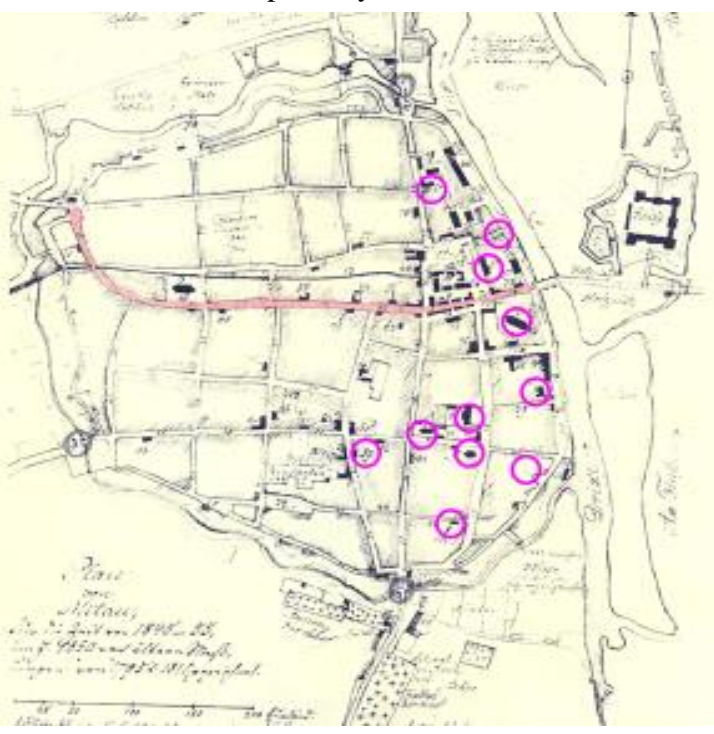

Fig. 10. Tower spires of the city's skyline along the left bank of the river Driksa.

The early $20^{\text {th }}$ century [Source: JHAM]

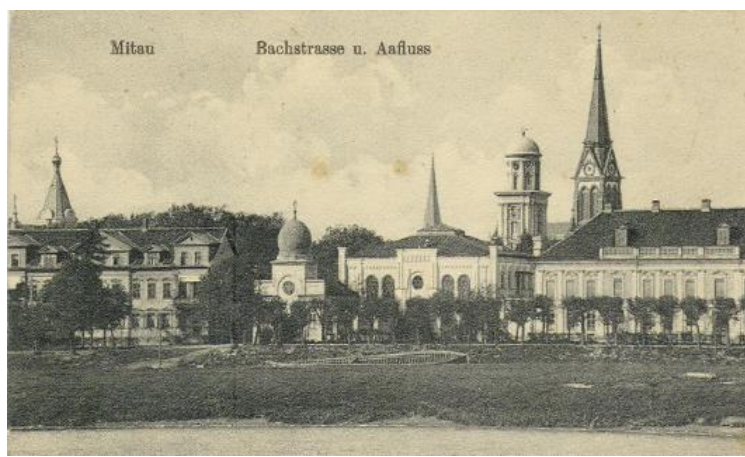

Fig. 11. Church spires silhouetted against the south. The early $20^{\text {th }}$ century [Source: JHAM]

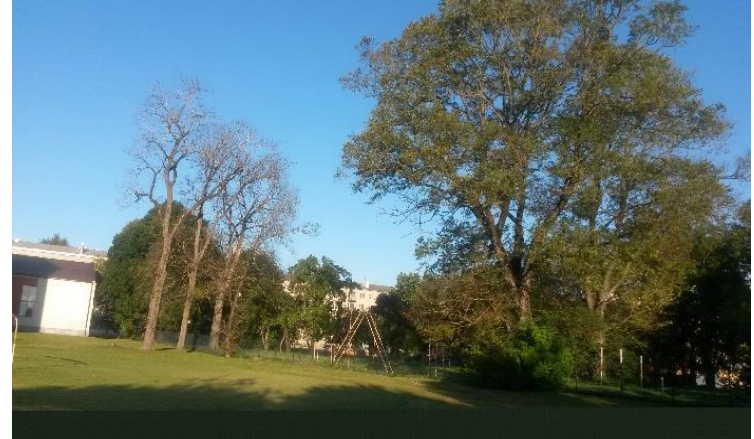

Fig. 12. Today, the historical location of the Reformed Church is marked by the old trees [Source: photo by author, 2017]

spires are prominent in the skyline. Of these mentioned above, the synagogue and the Nikolai Church have disappeared after the war. In this zone of the silhouette, the red-brick tower of the St. George's Church was the highest one that in the Neo-Gothic forms was rebuilt in 1906. Each of the the above spires formed a specific compositional character of the urban space. So, for instance, by ranging one tower after the other in the distance of $100 \mathrm{~m}$, in the silhouette, a spatial effect was formed by the synagogue, Academia Petrina, and St. George's Church. In turn, in the urban space, the St. Nicholas, St. John's and St. George's Church are located at the same distance $(300 \mathrm{~m})$, forming a triangle with equal sides in the plan (Fig. 11).

In the southern part, the silhouette line is concluded by the tower of the Nesterov House, St, John's Church, and the dome-shaped roof of the gas station. The St. John's Church marked the end place of the historic ramparts in the southern part. In the northern part of the silhouette, as mentioned above, the ramparts were concluded by the tower of the Reformed Church.

Today, Academia Petrina, St. George's Church, St. Simon's and St. Anne's Church, St. John's Church keep around themselves the green area or the garden.

Before the war, the Great Synagogue (1879, arch. J. Bārs) [8] marked a strong highlight of form creation in the silhouette of the city which was formed by a non-typical dome for the Latvian landscape instead of the tower spire (Fig. 15). In the postwar years, the historic building and its scale along the waterfront of the river Driksa from the Holy Trinity Church up to Uddens street has not been restored. Instead of the burned synagogue and the adjacent two-storey building, there is a seamless 5-storey building. On the opposite side of Ūdens street, instead of the disappeared 2-storey building, nowadays - a green area with a sports ground is located here. The penetration of the green zone in the silhouette of the historic building forms its shortening approximately on $80 \mathrm{~m}$. 


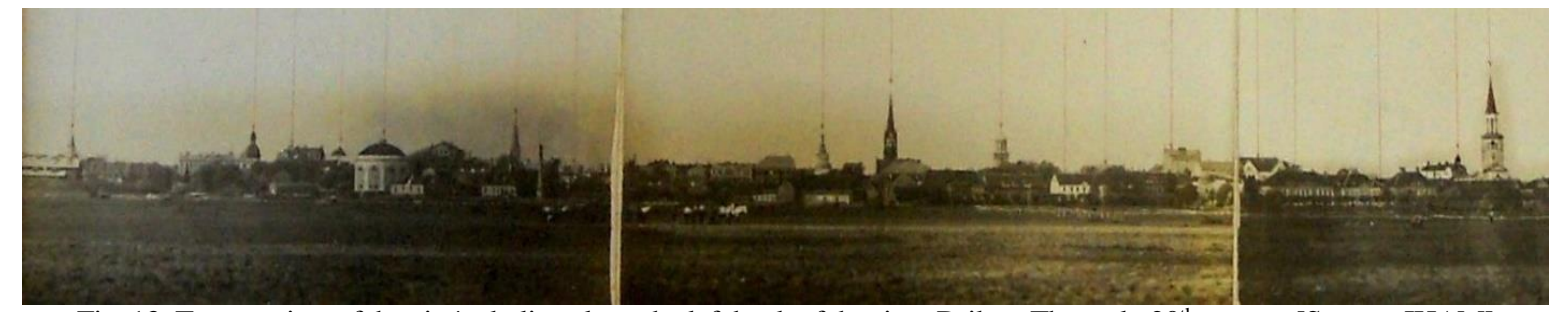

Fig. 13. Tower spires of the city's skyline along the left bank of the river Driksa. The early $20^{\text {th }}$ century [Source: JHAM]

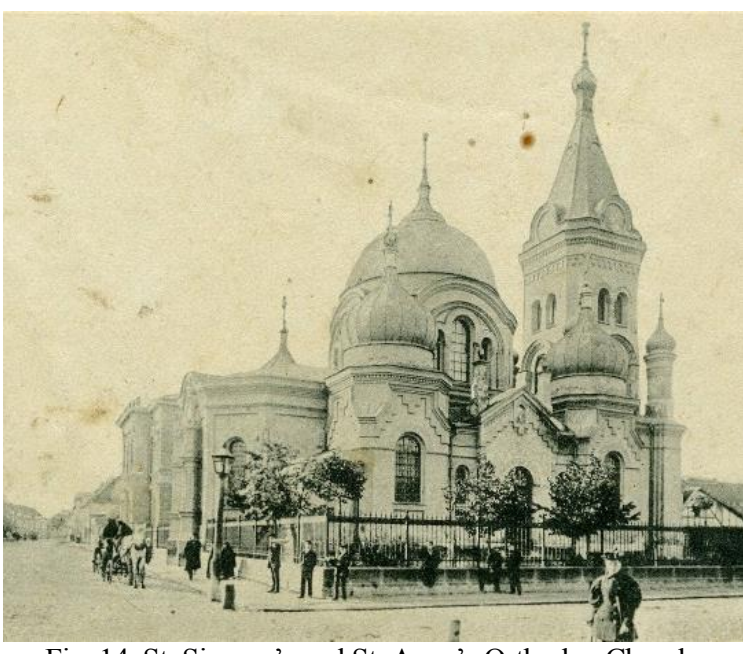

Fig. 14. St. Simeon's and St. Anne's Orthodox Church. The early $20^{\text {th }}$ century [Source: JHAM]

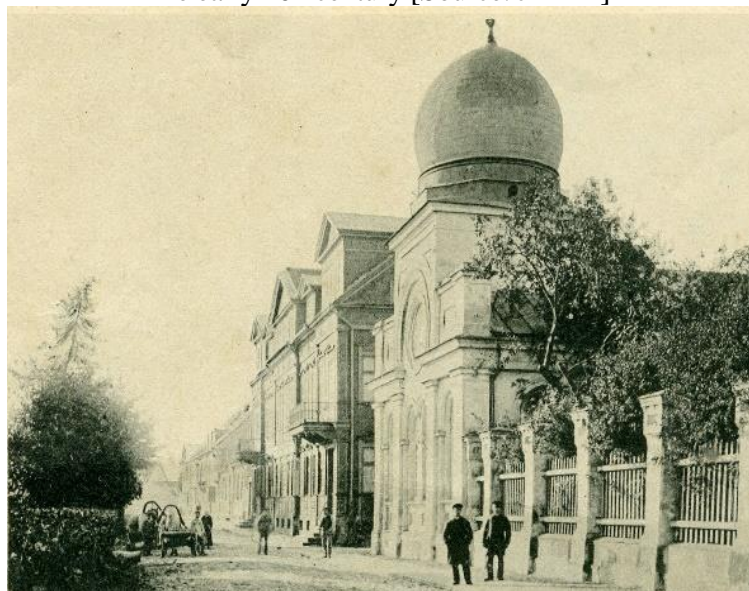

Fig. 15. The synagogue on the bank of the river Driksa promenade. The early $20^{\text {th }}$ century [Source: JHAM]

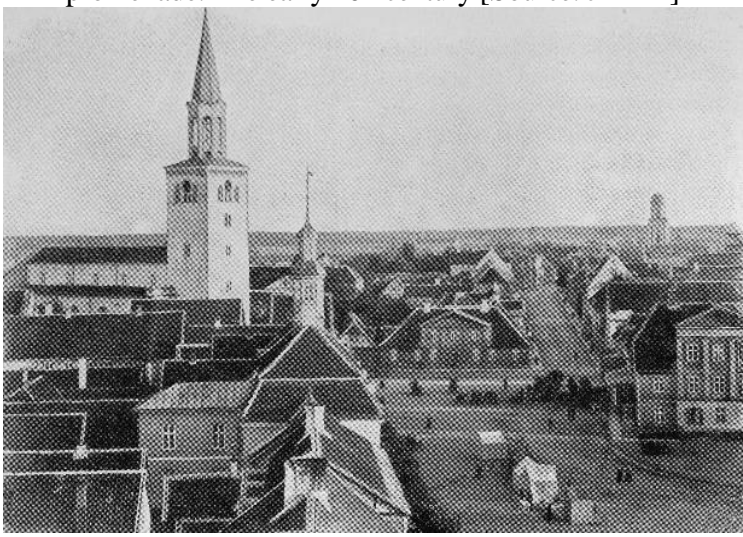

Fig.16. Landscape of the roof of the historic Market Square [Source: JHAM]

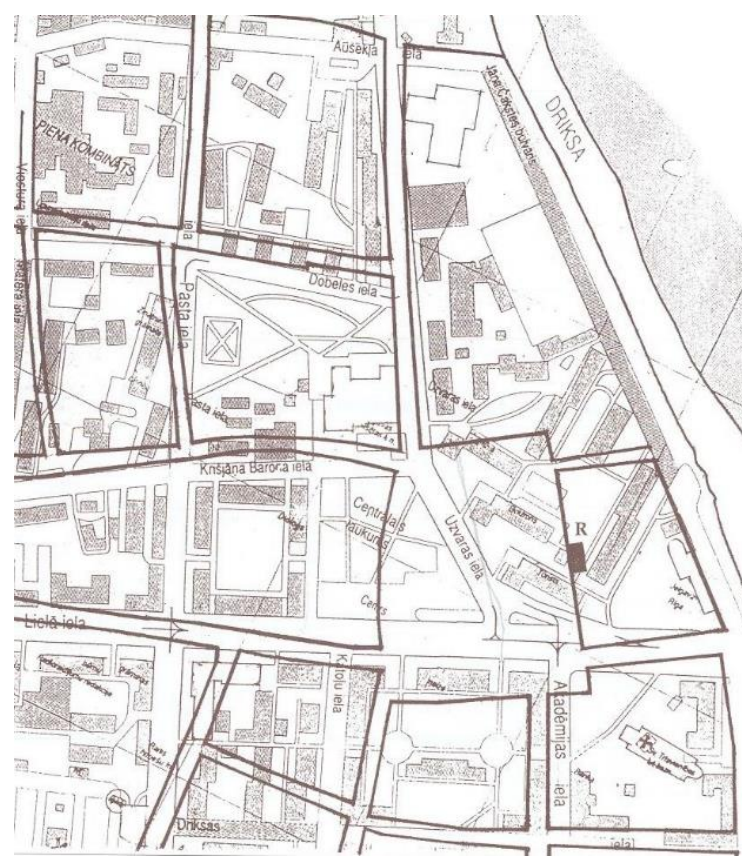

Fig. 17. The comparison of the historic

Market Square and today's street location [3]

The initial shape of the St. Simeon's and St. Anne's Orthodox Church (1892, arch. Chagin) was built according to the sketches of B. F. Rastrelli (Fig. 14). The rebuilding brought new dome and tower forms, keeping only individual fragments of the walls of the church built by Rastrelli $[8,9]$.

The Neo-Gothic tower mentioned in the silhouette of the St. John's Church (1882) was best visible from the railway bridge (see the historical photo). This line of sight is impressive even today. Until the war, when the building height around the place of worship did not exceed two or three storeys, the church spire in the silhouette was also visible from Pasta sala. $200 \mathrm{~m}$ away from the St.John's Church there was Ev. Lutheran Unity Church - the largest church in Zemgale (1904, k. Pēkšēns) mixed Neo-Romanic and Neo-Gothic forms.

By studying the historic carriage road into the city from the side of the river Lielupe, it should be noted that until World War II, it was $50 \mathrm{~m}$ away from the current bridge over the river Lielupe. Consequently, the perception of the southern part of the silhouette in the distant lines of sight was more pronounced. 


\section{Results and Discussion}

Assessing the character of the historic city skyline and skyline of modern building, it can be seen that:

- the height of the high-rise building in some viewpoints hides the church spires, so highlighting new vertical stresses. This is especially true for the southern skyline (building on Akadēmijas street and Driksas street);

- the modern building structure has acquired monotone planes and the plurality of forms in the architecture of the building facades is lost;

- the tiled roof character and the multifaceted roof planes have gone;

- the preservation of exaggeratedly large tree canopies hides the architectural shape of the towers (Ūdens street - Raina street);

- the spires as dominants formed stresses not only in the silhouette but also in the urban planning. For instance, the intersection of Ūdens street with the river Driksa promenade - the synagogue serves as an emphasis; the Reformed Church - as a connection point of Dobeles street with Uzvaras street.

St. Simeon's and St. Anne's Church - as the intersection point on Akadēmijas street; St. George's Church - the intersection of Katolu street, etc.. In turn, the Holy Trinity Church highlighted the corner of the Market Square.

The urban construction planning, its structure, the street network, and the language of the architectural, and compositional forms create a context that in the city's silhouette undeniably plays an important role. Especially brightly, it is attributable to the 2 periods of the construction of the city - in the situation of the prewar and postwar political power.

As in the $40 \mathrm{~s}$ of the $20^{\text {th }}$ century, by the compositional character, it is possible to divide the building of the embankment of the river Driksa in 2 zones: the downstream and upstream over the bridge of the river Driksa. Each of them has a different compositional structure and their length makes a building line about $100 \mathrm{~m}$ in length:

Upstream of the river, the embankment building is made up of a seamless 5-storey building, built in the 60 s of the $20^{\text {th }}$ century. Comparing both building periods, there is a different building height, structure, and form creation of the buildings.

Downstream of the Driksa bridge, the building of the embankment is characterized by a 3-storey hotel. Behind it, there are 5-storey residential buildings, which are positioned inclined against the waterfront. This position makes it possible to the green courtyard area be connected with the tree plantings of the embankment, which, in turn, reduces the expressiveness of the silhouetted building of the urban constructed space. In turn, while studying from the perspective of the ecological diversity and the green recreational space, the residential zone downstream of the Driksa bridge has gained a very strong character of the green area (Fig. 8). It is composed by:

- the courtyard tree plantations, broad lawns, and the green slope along the buildings, which serve as a back filling of the buildings' basement levels;

- the river bank landscape and a row of tree plantations;

- the view lines to the floodplain meadow on the opposite bank.

In the context of the construction of the embankment, the above green landscape is less pronounced in the upper reaches of the river than in the lower reaches. This applies to the placement of larger areas of the hard cover in the upper reaches:

- parking areas, the carriageway, pedestrian walkway, and the cycling area, concrete platforms as playgrounds;

- improvement elements of the pedestrian zone benches, lighting fixtures, design elements;

- the building volumes of the sport, leisure, and recreation area on the opposite bank;

- the exposition of the pedestrian bridge construction.

The compositional structure of the embankment silhouette in the lower and upper reaches has a different context, both in terms of the form creation and density of the green areas. This description has two aspects:

- nowadays, the silhouette of the city down the river Driksa is characterized by a residential area with a wide green landscape space. In turn, up to the $40 \mathrm{~s}$ of the $20^{\text {th }}$ century, there were 2-3-storey building units in this place, with an intensive economic activity alongside - fishing boat moorings and the exit to the Market Square. Alongside with the market pulsation, the Chivalry House belonging to the German nobility was located on the embankment, the architectural and compositional form of which was radically different from that of the building character readable in the silhouette. To a certain extent, both visually and psychologically, it clearly marked the city's German and Latvian peculiarities, both in the political and in the economic life.

Up to the $40 \mathrm{~s}$ of the $20^{\text {th }}$ century, upstream of the river, the modern building line of the embankment with public buildings was a location of residential houses with a walking area. Currently, the building of the silhouette is complemented by a concrete bank with boat moorings (Fig. 9). 


\section{Conclusions}

Like in any city in the world, Jelgava has also been affected by times of economic growth, which is reflected in the urban construction. Through the accumulation of layers of one construction period to another, the change of the boundary lines and stylistics of the construction phases are readable. Unfortunately, in the case of Jelgava, pages of such a history book are not readable, as the point of reference of the building history dates back to the 50 s of the $20^{\text {th }}$ century when the last rubbles of the war were removed from the streets of the city.

The information and assumptions about the church history in Jelgava are mostly based on the publications of Baltic German pastors and historians, the truth of which today is no longer possible to accurately verify. The church history studies in Jelgava have been carried out 140 years ago and during this time archives, libraries, and other important sources of reference have been irretrievably lost.

The changes of the silhouette on the left bank of the river Driksa can be divided into 3 main phases: up to the $40 \mathrm{~s}$ of the $20^{\text {th }}$ century, up to the 80 s of the $20^{\text {th }}$ century, and the start of the $21^{\text {st }}$ century. As mentioned in the research, only the last two phases are readable in the city's panorama. The perception of the silhouette of Jelgava in the viewing lines is influenced not only by the height of the building but also by the density and height of the trees. An important aspect of the silhouette, the location of the points of view is to be mentioned that plays an important role in attracting the infrastructure of tourism. This refers to the tasks of the urban construction planning, considering the opening or preservation of the viewing points, creating new buildings or tree planting zones.

\section{References}

1. Asaris, H. Latvijas pilsētas valsts divdesmit gados. Rīga: Latvijas Pilsētu savienība, 1938, pp. 210-242.

2. Apinis, K. Latvijas pilsētu vēsture. Rīga: A. Gulbis, 1931, pp. 182.-183.

3. Bākule, I. Rātsnami Latvijas pilsētās. Rīga: Zinātne, 2001, pp.107-117.

4. Dērings, J. Ko es nekad negribētu aizmirst. Rīga: Latvijas Nacionālais arhīvs, 2016. 878 p.

5. Grosmane, E. Senā Jelgava. Rīga: Neputns, 2010. 336 p.

6. Lancmanis, I. Jelgavas pils. Rīga: Zinātne, 2006, pp.14-16.

7. Schlau, K. O. Mitau im 19. Jahrhundert: Leben und Wirken des Bürgermeisters Franz von Zuccalmaglio (18001873). Wedemark-Elze: Harro v. Hirschheydt, 1995. 458 p.

8. Spārītis, O. Versija par Jelgavas Sv. Trīsvienības baznīcu. Jelgava: Jelgavas pilsētas pašvaldība, 2011. $334 \mathrm{p}$

9. Tomašūns, A. Mana Jelgava. Jelgava: Jelgavas pilsētas dome, 2015. 224 p.

\section{INFORMATION ABOUT AUTHOR:}

Aija Ziemeḷniece. Dr.arch. A.Ziemeḷniece is an prof. in Latvia University of Agriculture, specialized in fields cultural heritage, study of transformation processes of urban landscape. E-mail:aija@k-projekts.lv

Kopsavilkums. Gan Jelgavas vēsturiskais karšu materiāls, gan senās gravīras liecina par pilsētai raksturīgu siluetu ar daudzām dievnamu smailēm. Attīstoties fotogrāfiskā attēla iegūšanas iespējām, dokumentālais materiāls īpaši spilgti 20.gs 20.-30.g. liecina par vēsturiskā pilsētas silueta izteiksmīgumu. Pateicoties dokumentētajam materiālam, ir iespējams veikt pilsētbūvnieciskās telpas izpēti pa atsevišķām dievnamu apbūves zonām gar Driksas kreiso krastu, kur iepretim hercogistes mītnes vietai - Jelgavas pilij, izvietojās pilsētas vāciskās aristokrātijas lepnākie nami.

Jelgavas siluets ar dievnamu smailēm gadu simtos ir mainījies vairākkārtīgi. Tā arhitektoniski ainaviskās izteiksmes kulminācija pastāvēja līdz otrajam pasaules karam, līdz pilsēta tika nežēlīgi nodedzināta un vēsturiskās apbūves atjaunošana tika ignorēta. Mainoties ǵeopolitiskajai situācijai, mainās līdzi pilsētas apbūves blīvums, augstums un siluets. Jelgava ir spilgts piemērs politiskās varas izpausmēm, kas ir attiecināms nevien uz dievnamu atjaunošanu vai demontāžu 20.gs.50.g. Reizē tas ir divu sabiedrības politisko spēku salīdzinājums sapratnei par pilsētas apbūves kultūrvēsturiskā mantojuma vērtībām. Pēckara gados jēdziens "sapratne” ir ar slēptu nozīmi, iznīcinot t.s. kapitālisma laika mantojumu kultūrā, mākslā un arhitektūrā.

Kā spožākais akcents Jelgavas siluetā pastāvēja vācu ev.lut. Sv. Trīsvienības baznīca, simbolizējot pilsētas garīgo varu. Tai līdzās - administratīvās varas simbols - Rātsnams ar smaili un vācu Bruṇniecības nams. Trīs spēcīgi vāciskās vides simboli Jelgavas pilsētas silueta centrā - skaidri iezīmēja pilsētas kultūrvēsturisko lappusi Driksas kreisā krastā.

20.gs. 20.-30. gadi atnes jaunās Latvijas valsts politisko varu un tās attieksmi pret vācisko pilsētvidi. Varas maiņas izpausmes aizsākas ar Bruṇniecības nama demontāža 20. gs. 30. g. un jaunas viesnīcas būvniecību tajā pašā vietā, ienesot pilsētas siluetā citu akcentu.

Mūsdienu Jelgavas siluets Driksas kreisā krastā ir 20. gs. 60.-70. g. mantojums, kurā ir nolasāms apbūves uzslāņojums pēdējo simts gadu laikā, nesot līdzi jaunu struktūru, mērogu, proporcijas un zaḷo platību blīvumu. 